\title{
Current red cell transfusion practice: are we too liberal with this precious resource?
}

\author{
Authors: Diana Slim, ${ }^{\mathrm{A}}$ Susannah Rynhart, ${ }^{\mathrm{A}}$ Mathew Sheridan, ${ }^{\mathrm{A}}$ Rahul Shrimanker ${ }^{\mathrm{A}}$ and Emily Bowen ${ }^{\mathrm{A}}$
}

\section{Introduction}

Current National Institute for Health and Care Excellence (NICE) guidance recommends restrictive thresholds for red cell transfusion, dependent upon patient factors such as haemodynamic status. ${ }^{1}$

NICE also recommends that individuals should be provided with information regarding the risks and benefits of blood transfusion and those patients should give informed consent prior to blood transfusion.

Informed consent is a recurrent theme in the Infected Blood Inquiry. ${ }^{2}$

We audited red cell transfusion (RCTx) practices according to NICE guidelines and examined documentation around consent.

\section{Materials and methods}

The study consisted of 4 parts.

> Part 1: Audit of medical inpatients in receipt of RCTx between January and March 2018. Data were collected on indication for transfusion, comorbidities and eligibility for a restrictive approach.

> Part 2: Review of written documentation in the patient records on information given and consent to RCTx.

$>$ Part 3: Data on length of stay and mortality following RCTx.

> Part 4: Online survey of doctors questioning practice around documentation of information provided and consent to RCTx. The survey also included two clinical cases to examine whether clinicians used a restrictive threshold or not.

\section{Results and discussion}

\section{Part 1}

Records of 82 patients were evaluated. Table 1 outlines the main indications for RCTx using the national blood transfusion codes. ${ }^{3}$ Median baseline haemoglobin ( $\mathrm{Hb}$ ) pre-transfusion was $69 \mathrm{~g} / \mathrm{L}$ (interquartile range (IQR) 66-76) and post-transfusion was $85 \mathrm{~g} / \mathrm{L}$ (IQR 80-96); median number of units of blood transfused was 2 units; $89 \%$ of patients were eligible for a restrictive approach but this was practised in only $40 \%$ of patients; $86 \%$ of patients had their $\mathrm{Hb}$ checked in the $12-24$ hours following transfusion and $57 \%$ had $\mathrm{Hb}$ checked after each individual unit excluding those that died.

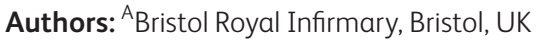

\section{Table 1. Main indications for red cell transfusion}

\begin{tabular}{|c|c|c|c|}
\hline Indications & $\begin{array}{l}\text { Not suitable } \\
\text { for restrictive } \\
\text { transfusion, } \\
\text { n (\%) }\end{array}$ & $\begin{array}{l}\text { Suitable for } \\
\text { restrictive } \\
\text { transfusion, } \\
\text { n (\%) }\end{array}$ & $\begin{array}{l}\text { Total, } \\
\text { n (\%) }\end{array}$ \\
\hline $\begin{array}{l}\text { Acute } \\
\text { bleeding with } \\
\text { haemodynamic } \\
\text { instability }\end{array}$ & $3(3.7)$ & $4(4.9)$ & $7(8.5)$ \\
\hline $\begin{array}{l}\text { Haemoglobin } \\
\leq 70 \mathrm{~g} / \mathrm{L} \text { (stable } \\
\text { target } 70-90 \mathrm{~g} / \mathrm{L} \text { ) }\end{array}$ & $1(1.2)$ & $55(67.1)$ & $56(68.3)$ \\
\hline $\begin{array}{l}\text { Haemoglobin } \\
\leq 80 \mathrm{~g} / \mathrm{L} \\
\text { (stable target } \\
80-100 \mathrm{~g} / \mathrm{L} \text { if } \\
\text { cardiovascular } \\
\text { disease) }\end{array}$ & $1(1.2)$ & $12(14.6)$ & $13(15.9)$ \\
\hline $\begin{array}{l}\text { Chronic } \\
\text { transfusion } \\
\text { dependent } \\
\text { anaemia }\end{array}$ & $3(3.7)$ & $2(2.4)$ & $5(6.1)$ \\
\hline $\begin{array}{l}\text { Radiotherapy } \\
\text { haemoglobin } \\
\leq 110 \mathrm{~g} / \mathrm{L}\end{array}$ & $1(1.2)$ & $0(0)$ & $1(1.2)$ \\
\hline Total & $9(11.0)$ & $73(89.0)$ & $82(100)$ \\
\hline
\end{tabular}

\section{Part 2}

Sixty-nine records were reviewed for documentation around consent and information, Table 2 shows the breakdown. It was assumed patients with cognitive impairment were treated in their best interest. In patients with no history of cognitive impairment $(n=48)$, only $35 \%$ had evidence of consent documented.

Part 3

Haematological or solid organ palliative malignancy was recorded in 24 patients. Median length of stay was 13.5 days; $55 \%$ of patients died within 6 months of discharge and $60 \%$ within 12 months. 


\begin{tabular}{|c|c|c|c|}
\hline Consent & $\begin{array}{l}\text { Information } \\
\text { given, } \mathrm{n}(\%)\end{array}$ & $\begin{array}{l}\text { Information } \\
\text { not given, } \mathrm{n}(\%)\end{array}$ & $\begin{array}{l}\text { Unknown, } \\
\text { n (\%) }\end{array}$ \\
\hline Assumed & $1(1.2)$ & $18(22.0)$ & $2(2.4)$ \\
\hline No & $0(0)$ & $31(37.8)$ & $0(0)$ \\
\hline Yes & $11(13.4)$ & $5(6.1)$ & $1(1.2)$ \\
\hline Unknown & $0(0)$ & $0(0)$ & $13(15.9)$ \\
\hline
\end{tabular}

\section{Part 4}

There were 37 responses from a wide spectrum of training grades; $73 \%$ stated they always or sometimes obtained consent prior to RCTx, but only $40 \%$ document this consent process; $90 \%$ of respondents gave the reason for transfusion but about $50 \%$ would discuss the risks; over $75 \%$ of individuals would use a restrictive transfusion threshold depending on clinical history.

\section{Conclusion}

Despite clear guidelines, restrictive transfusions were not used: most patients received two units regardless of target or initial $\mathrm{Hb}$; most patients did not have an $\mathrm{Hb}$ checked post each unit - which would guide the need for further units; and consent to transfusion and provision of information surrounding it is poorly documented. We plan to deliver education sessions to all clinicians in our trust and re-audit our practice following this.

\section{Conflicts of interest}

None declared.

\section{References}

1 National Institute for Health and Care Excellence. Blood transfusion. NICE guideline [NG24]. NICE, 2015. www.nice.org.uk/ guidance/ng24 [Accessed 25 October 2019].

2 Infected Blood Inquiry. Terms of reference. IBI, 2018. www. infectedbloodinquiry.org.uk [Accessed 25 October 2019].

3 National Blood Transfusion Committee. Indication codes for transfusion - an audit tool. NHS, 2016. www.transfusionguidelines. org/document-library/documents/nbtc-indication-codes-june2016v2 [Accessed 25 October 2019]. 